\title{
PENERAPAN PEMBELAJARAN KOOPERATIF TIPE NUMBERED HEADS TOGETHER (NHT) PADA MATERI GERAK PARABOLA DAN GERAK MELINGKAR MELALUI KEGIATAN LESSON STUDY
}

\author{
Wari Prastiti \\ SMA Negeri 5 Metro \\ Email: wari.prastiti78@gmail.com
}

\begin{abstract}
Abstrak
Penelitian ini bertujuan untuk meningkatkan aktivitas belajar fisika materi gerak parabola dan gerak melingkar siswa kelas XI IPA 1 SMA Negeri 5 Metro Tahun Pelajaran 2014/2015 dengan penerapan pembelajaran kooperatif tipe Numbered Heads Together (NHT) melalui kegiatan Lesson Study. Metode penelitian yang digunakan pada penelitian ini adalah Penelitian Tindakan Kelas (PTK) yang dilaksanakan dalam dua siklus. Setiap siklus diawali dengan tahap plan kemudian dilanjutkan do dan see/refleksi. Subyek penelitian adalah siswa kelas XI IPA 1 SMA Negeri 5 Metro Tahun Pelajaran 2014/2015. Data diperoleh melalui observasi menggunakan lembar observasi aktivitas belajar dan dianalisis secara deskriptif kualitatif. Berdasarkan hasil penelitan dapat disimpulkan bahwa penerapan pembelajaran kooperatif tipe NHT dapat meningkatkan aktivitas belajar siswa XI IPA 1 SMA Negeri 5 Metro Tahun Pelajaran 2014/2015 . Hal ini terlihat dari hasil siklus I dan siklus II terjadi peningkatan aktivitas belajar pada tiap indikator aktivitas belajar yang ditentukan.
\end{abstract}

Kata Kunci: Numbered Heads Together, Aktivitas, Lesson Study

\section{PENDAHULUAN}

Perbaikan dan peningkatan proses pembelajaran di segala tingkat terus menerus dilaksanakan. Berbagai upaya telah dilaksanakan untuk meningkatkan mutu pembelajaran. Sejalan dengan visi Kota Metro sebagai kota pendidikan, maka SMAN 5 Metro sebagai salah satu sekolah menengah atas yang berada di wilayah tersebut berupaya mendukung pemerintah setempat untuk mewujudkan cita-cita tersebut. Strategi yang dikembangkan SMA Negeri 5 Metro meliputi tiga hal pokok, yaitu: penataan kelembagaan, peningkatan mutu pembelajaran, dan peningkatan mutu profesi tenaga pendidik dan kependidikan.

Salah satu strategi yang diterapkan di SMAN 5 Metro adalah meningkatkan mutu pembelajaran. Inti 
Wari Prastiti - Penerapan Pembelajaran Kooperatif ...

dari proses pendidikan adalah pembelajaran. Dalam Undang-Undang No. 20 Tahun 2003 Tentang Sistem Pendidikan Nasional pasal 1 ayat 20 dinyatakan bahwa pembelajaran adalah proses interaksi siswa dengan pendidik dan sumber belajar suatu lingkungan belajar. Pembelajaran merupakan bantuan yang diberikan pendidik agar siswa dapat mengembangkan potensi dirinya, sehingga pada akhirnya siswa dapat memiliki sikap positif, mengembangkan kecerdasan intelektual dan mengembangan keterampilannya.

Pembelajaran merupakan sebuah sistem yang terdiri dari beberapa komponen. Salah satu komponen yang berperan dalam pembelajaran adalah guru. Hal ini disebakan guru merupakan orang yang secara langsung berhadapan dengan siswa (Sanjaya, 2011:15). Kurikulum pendidikan yang baik, sarana prasarana yang lengkap, akan kurang bermakna apabila tidak diimbangi dengan kemampuan guru dalam mengimplementasikannya. Pembelajaran yang berkualitas sangat tergantung pada kemampuan guru dalam mengelola pembelajaran yang dilakukannya.
Upaya peningkatan mutu guru telah dilakukan oleh pemerintah, melalui pemberian sertifikasi, uji kompetensi, penilaian kinerja, pengembangan keprofesian berkelanjutan dan pelatihan-pelatihan. Upaya-upaya tersebut bersifat top down. Namun dirasakan sejauh ini, upaya yang telah dilakukan belum mencapai tujuan yang diharapkan. Diperlukan suatu formula lain, salah satu upaya peningkatan profesionalisme guru dalam rangka menciptakan pembelajaran yang lebih baik adalah melalui lesson study yang bersifat bottom up, karena berbasis permasalahan yang dihadapi guru di kelas, kemudian dikaji secara kolaboratif secara berkelanjutan.

Program lesson study merupakan salah satu langkah yang diambil oleh pimpinan SMAN 5 Metro. Pihak sekolah menginginkan adanya reformasi sekolah yaitu kegiatan atau upaya-upaya pembaharuan yang dilakukan untuk meningkatkan efisiensi layanan pembelajaran bagi siswanya. Ini dapat dimaknai sebagai perubahan paradigma yang akan menyebabkan perubahan yang berpengaruh pada operasional sekolah, dan perbaikan lingkungan sekolah agar 
Wari Prastiti - Penerapan Pembelajaran Kooperatif ...

proses belajar siswa dan guru menjadi

Berikut ini ditampilkan input data optimal.

siswa baru kota Metro pada

Hal ini dilatarbelakangi bahwa input siswa di SMAN 5 Metro pada penerimaaan tahun pelajaran 2013/2014.tahun ajaran 2013 input ini menjadi output yang lebih baik. Pada dasarnya sekolah ungggul adalah sekolah yang fokus pada menempati urutan ke -4 dari enam sekolah menengah atas yang berada di kota Metro (Tabel 1).

kualitas proses pembelajaran, bukan pada kualitas input siswanya (Chatib, 2014: 93).

Tabel 1. Data Input Siswa SMA Negeri di Metro Tahun 2013/2014

\begin{tabular}{|c|l|l|l|}
\hline Nama Sekolah & \multicolumn{1}{|c|}{ Terendah } & Tertinggi & Rerata rata \\
\hline SMAN 1 METRO & 28.300 & 37.800 & 34.132 \\
\hline SMAN 2 METRO & 18.150 & 34.750 & 26.036 \\
\hline SMAN 3 METRO & 24.550 & 36.850 & 30.599 \\
\hline SMAN 4 METRO & 24.450 & 35.000 & 28.812 \\
\hline SMAN 5 METRO & 20.400 & 35.550 & 27.305 \\
\hline SMAN 6 METRO & 13.950 & 36.700 & 25.554 \\
\hline
\end{tabular}

Sumber : Arsip PPDB SMA Kota Metro Tahun 2013/2014

Hal tersebut menunjukkan bahwa input siswa masih tergolong sedang, sehingga memerlukan upaya yang lebih dari pihak sekolah untuk mengolah

Selain itu diperoleh informasi bahwa di SMA Negeri 5 Metro, capaian hasil belajar siswa untuk mata pelajaran fisika masih kurang menggembirakan. Hasil belajar fisika kelas X pada ujian akhir semester genap semester 2 SMA Negeri 5 Metro tahun pelajaran 2013/2014 diperoleh hasil $25 \%$ siswa yang mencapai ketuntasan. Batas ketuntasan belajar minimum yang ditetapkan adalah 70 . Berarti hasil belajar berdasarkan Kurikulum Tingkat Satuan Pendidikan (KTSP) dimana jumlah siswa yang mendapat nilai 70 ke atas minimum 75 $\%$ tidak terpenuhi. Hal ini menunjukkan bahwa rata- rata nilai fisika siswa kelas X SMA Negeri 5 Metro masih rendah.

Beberapa penyebab rendahnya mutu pembelajaran (Dikti,2010:3), antara lain sebagai berikut : (a) pada 
Wari Prastiti - Penerapan Pembelajaran Kooperatif ...

umumnya dosen/guru bekerja sendirian dalam melaksanakan pembelajaran. Apabila guru tersebut inovatif dalam membelajarkan peserta didknya maka kreativitasnya tidak berimbas tehadap guru lain karena tidak ada sharing di antara guru yang lain, (b) pada umumnya guru memiliki ego yang tinggi, merasa super, tidak mudah menerima masukan untuk perbaikan pembelajaran, terlebih guru yang senior dari segi lamanya mengajar. Padahal tidak ada pembelajaran yang sempurna , selalu ada celah untuk perbaikan. Mindset guru perlu diperbaiki agar guru dapat berkolaborasi dan mau sharing dengan guru lain serta terbuka untuk perbaikan kualitas pembelajaran.

Berdasarkan dari permasalahan tersebut di atas, pihak sekolah berupaya melakukan suatu perubahan. Sekolah sebagai suatu organisasi sudah selayaknya melakukan perubahan, mengingat banyaknya tantangan dan persaingan. Tujuan dari pihak sekolah mengadakan perubahan adalah adanya keinginan untuk meningkatkan performa, meningkatkan kualitas, memberikan pelayanan yang lebih baik. Kebijakan yang diambil oleh pihak sekolah untuk melakukan perubahan adalah melalui lesson study.
Lesson study adalah model pembinaan profesi pendidik melalui pengkajian pembelajaran secara kolaboratif dan berkelanjutan berlandaskan prinsip - prinsip kolegialitas dan mutual learning untuk membangun karakter guru dan dosen (Hendayana, 2012: 4). Lewis dalam Syamsuri ( 2008 : 27) menyatakan “ lesson study is cycle in which teachers work together to consider their longterm goals for students, bring those goals to life in actual " research lessons," and collaboratively observe , discuss, and refine the lessons" . Ide yang terkandung di dalam lesson study ialah jika seorang guru ingin meningkatkan pembelajaran, salah satu cara yang paling jelas adalah melakukan kolaborasi dengan guru lain untuk merancang, mengamati dan melakukan refleksi terhadap pembelajaran yang dilakukan.

Apabila dicermati definisi lesson study, maka ada bebarapa kata kunci, yaitu pembinaan profesi, pengkajian pembelajaran, kolaboratif, berkelanjutan, kolegialitas, saling belajar dan komunitas belajar. Lesson study bertujuan untuk melakukan pembinaan profesi pendidik secara berkelanjutan agar terjadi peningkatan 
Wari Prastiti - Penerapan Pembelajaran Kooperatif ...

profesionalitas pendidik terus menerus

Berikut ini disajikan gambar 1 pernah berakhir (continous siklus lesson study.

improvement).

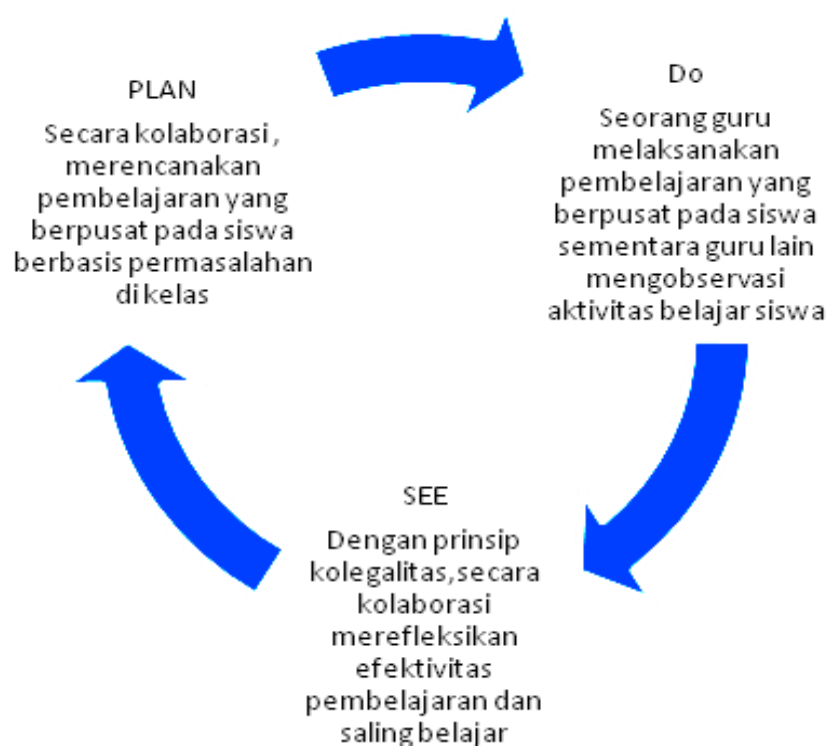

Gambar 1: Siklus Pengkajian Pembelajaran dalam lesson study (Sumber : buku panduan implementasi lesson study di LPTK ).

Pembelajaran kooperatif merupakan pembelajaran yang memberikan kesempatan kepada siswa untuk bekerja sama dengan sesama siswa dalam tugas - tugas terstruktur, sehingga diharapkan terjadinya interaksi yang efektif diantara anggota kelompok. (Chotimah dan Dwitasari, 2009: 2). Model pembelajaran kooperatif memiliki banyak tipe, salah satu diantaranya adalah tipe Numbered Heads Together (NHT). NHT adalah merupakan jenis pembelajaran kooperatif yang dirancang untuk memengaruhi pola interaksi siswa dan sebagai alternatif terhadap struktur kelas tradisional, yang dikembangkan pertama kali oleh Spenser Kagen (Trianto, 2010:82).

Dalam pembelajaran kooperatif tipe NHT guru menggunakan struktur empat fase , yaitu (1) penomoran; dalam fase ini guru membagi siswa ke dalam kelompok . Setiap siswa di dalam kelompok diberi nomor antara 1 sampai 5, (2) mengajukan pertanyaan; guru memberi tugas/pertanyaan dan masing - masing kelompok 
Wari Prastiti - Penerapan Pembelajaran Kooperatif ...

mengerjakannya , (3) berpikir bersama, pada fase ini siswa menyatukan pendapatnya terhadap jawaban pertanayaan itu dan meyakinkan tiap anggota dalam timnya mengetahui jawaban tim dan (4) menjawab pertanyaan, fase ini guru memanggil suatu nomor tertentu, kemudian nomor yang dipanggil melaporkan hasil kerjasama mereka.

$$
\text { Hasil penelitian }
$$

Kusumaningtyas (2014) menunjukkan pembelajaran kooperatif tipe Numbered Head Together dapat meningkatkan aktivitas belajar , lebih lanjut (Novelensia, 2014) tentang penerapan pembelajaran kooperatif tipe NHT disertai metode eksperimen dalam pembelajaran fisika di SMA menunjukkan bahwa aktifitas belajar siswa dalam pembelajaran sangat aktif sebesar 82,55\%. Daud dan Fausan (2011) menemukan bahwa penerapan model pembelajaran kooperatif NHT (Numbered Head Together) pada konsep ekosistem dapat meningkatkan kegiatan belajar dan hasil belajar siswa.

Melalui model pembelajaran kooperatif tipe Numbered Head Together (NHT), diharapkan siswa dapat berpartisipasi aktif dan dapat bekerja sama dengan baik secara kooperatif. Berdasarkan latar belakang di atas penulis tertarik untuk mengadakan penelitian dengan judul “ Implementasi strategi pembelajaraan kooperatif tipe NHT (Numbered Head Together) dalam upaya meningkatkan partisipasi siswa pada materi gerak parabola dan gerak melingkar berbasis Lesson Study di SMA Negeri 5 Metro.

\section{METODE PENELITIAN}

Jenis penelitian ini adalah penelitian tindakan kelas melalui kegiatan lesson study yang dilakukan pada kelas XI IPA $A_{1}$ dengan menggunakan sebanyak dua siklus pengamatan, dimana setiap siklus terdiri dari dua pertemuan yang bertujuan untuk melihat peningkatan partisipasi siswa dalam pembelajaran. Dengan menerapkan tahapan - tahapan pada lesson study, yaitu plan, do dan seelrefleksi.

Teknik pengumpulan data dalam penelitian tindakan ini adalah observasi, hasilnya dipergunakan untuk memperoleh data tentang aktivitas belajar siswa. Data yang diperoleh pada setiap kegiatan observasi dari setiap siklus, dianalisis secara deskriptif dengan menggunakan teknik persentase 
Wari Prastiti - Penerapan Pembelajaran Kooperatif ...

untuk melihat kecenderungan yang dikategorikan. Kriteria aktivitas belajar terjadi dalam proses pembelajaran. siswa dapat dilihat pada Tabel 2 berikut Kegiatan analisis meliputi tingkat ini :

partisipasi atau keaktifan siswa dalam

proses pembelajaran kemudian

Tabel 2. Kategori Skor

\begin{tabular}{|c|c|c|}
\hline No & Pedoman & Kategori \\
\hline 1. & $90 \%-100 \%$ & Sangat Aktif \\
\hline 2. & $75 \%-90 \%$ & Aktif \\
\hline 3. & $50 \%-75 \%$ & Cukup Aktif \\
\hline 4. & $<50 \%$ & Kurang Aktif \\
\hline
\end{tabular}

Sumber : Arikunto (1988: 130)

\section{HASIL DAN PEMBAHASAN}

Kegiatan plan I dilaksanakan tanggal 11 Agustus 2014 di ruang guru SMA Negeri 5 Metro, dihadiri oleh empat orang tim lesson study sekolah dan tiga orang mahasiswa PPL . Kegiatan ini berisi pemaparan RPP yang sudah dibuat oleh guru model. Siklus I direncanakan sebanyak tiga pertemuan.

Kegiatan do dan see siklus I dilaksanakan pada tanggal 13,15 dan 20 Agustus 2014 dengan alokasi waktu pertemuan ke -1 adalah 3 x 45 menit dan pertemuan ke -2 dan ke -3 adalah 2 x 45 menit. Sebagai guru model adalah peneliti dan sebagai observer adalah tim lesson study dibantu mahasiswa PPL.

Pada Tabel 3 data aktivitas belajar seluruh siswa pada siklus I. Berdasarkan hasil tindakan siklus I dan pengamatan guru observer terlihat bahwa aktivitas siswa secara keseluruhan dapat dikategorikan cukup aktif yaitu nilai rata- rata aktivitas siswa untuk semua indikator mencapai $67,74 \%$. Secara umum peneliti telah berusaha dalam melaksanakan pembelajaran dengan menerapkan pembelajaran kooperatif tipe NHT, namun masih ada beberapa hal yang perlu peneliti perbaiki terkait dengan pengelolaan pembelajaran, di antaranya manajemen waktu, bimbingan pada 
Wari Prastiti - Penerapan Pembelajaran Kooperatif ...

\section{siswa saat bekerja kelompok serta} penegasan kembali materi di akhir pembelajaran. Temuan pada siklus I ini menjadi rekomendasi pada perbaikan siswa selama pembelajaran mengalami peningkatan aktivitas dari siklus I ke siklus II . Pada siklus satu diperoleh $67,74 \%$ dengan kategori cukup aktif

Tabel 3. Data persentase aktivitas belajar siswa siklus I

\begin{tabular}{|c|l|c|c|}
\hline No & \multicolumn{1}{|c|}{ Indikator } & Persentase & Kategori \\
\hline 1 & $\begin{array}{l}\text { Kemampuan siswa dalam } \\
\text { bertanya }\end{array}$ & 49,11 & kurang aktif \\
\hline 2 & $\begin{array}{l}\text { Kemampuan siswa dalam } \\
\text { mengungkapkan } \\
\text { pendapat }\end{array}$ & 69,64 & cukup aktif \\
\hline 3 & $\begin{array}{l}\text { Kemampuan dalam } \\
\text { merangkai alat percobaan }\end{array}$ & 75,89 & aktif \\
\hline 4 & $\begin{array}{l}\text { Kemampuan dalam } \\
\text { menggunakan alat } \\
\text { percobaan }\end{array}$ & 79,46 & aktif \\
\hline 5 & $\begin{array}{l}\text { Kemampuan dalam } \\
\text { mengambil data } \\
\text { percobaan }\end{array}$ & 72,32 & cukup aktif \\
\hline 6 & $\begin{array}{l}\text { kemampuan menarik } \\
\text { kesimpulan }\end{array}$ & 60,71 & cukup aktif \\
\hline 7 & $\begin{array}{l}\text { Interaksi siswa dalam } \\
\text { menerima materi selama } \\
\text { proses pembelajaran }\end{array}$ & 70,53 & cukup aktif \\
\hline 8 & $\begin{array}{l}\text { Interaksi siswa dalam } \\
\text { diskusi kelompok }\end{array}$ & 64,28 & cukup aktif \\
\hline \multicolumn{2}{|c|}{ Rerata } & 67,74 & cukup aktif \\
\hline
\end{tabular}

tindakan pada siklus II, melalui kegiatan plan diupayakan penyempurnaannya secara kolaborasi dengan tim yang terlibat dalam lesson study.

Kegiatan do dan see pada siklus II dilaksanakan pada tanggal 22, 37 dan 29 Agustus. Data aktivitas belajar siswa disajikan pada Tabel 4. Berdasarkan hasil pengamatan aktivitas dan siklus II sebesar 78, 87\% dengan kategori aktif. Grafik rata - rata aktivitas siswa pada siklus I dan siklus II disajikan pada gambar 2.

Peningkatan aktivitas siswa dengan menerapkan pembelajaran kooperatif tipe NHT ini dimungkinkan oleh beberapa hal. IDCJ ( 2012 : 15) menjelaskan perlunya kegiatan secara berkelompok yakni : (1) siswa yang 
Wari Prastiti - Penerapan Pembelajaran Kooperatif ...

lambat dapat belajar lebih baik dengan bantuan siswa yang cepat menangkap pelajaran,

(2) siswa yang cepat menangkap pelajaran dapat memperdalam pemahaman dengan memberi penjelasan suatu subjek pada siswa yang lambat, (3) siswa dapat menyelesaikan permasalahan dengan mendengarkan dan memanfaatkan pemikiran dan gagasan siswa lain, (4) siswa dapat membangun hubungan yang lebih baik dengan satu sama lain.

Tabel 4. Data Aktivitas Belajar Siswa Pada Siklus II

\begin{tabular}{|c|l|c|c|}
\hline No & \multicolumn{1}{|c|}{ Indikator } & Persentase & Kategori \\
\hline 1 & Kemampuan siswa dalam bertanya & 48,21 & kurang aktif \\
\hline 2 & $\begin{array}{l}\text { Kemampuan siswa dalam mengunkapkan } \\
\text { pendapat }\end{array}$ & 72,32 & aktif \\
\hline 3 & $\begin{array}{l}\text { Kemampuan dalam merangkai alat } \\
\text { percobaan }\end{array}$ & 83,92 & aktif \\
\hline 4 & $\begin{array}{l}\text { Kemampuan dalam menggunakan alat } \\
\text { percobaan }\end{array}$ & 96,42 & sangat aktif \\
\hline 5 & $\begin{array}{l}\text { Kemampuan dalam mengambil data } \\
\text { percobaan }\end{array}$ & 78,57 & aktif \\
\hline 6 & kemampuan menarik kesimpulan & 76,67 & aktif \\
\hline 7 & $\begin{array}{l}\text { Interaksi siswa dalam menerima materi } \\
\text { selama proses pembelajaran }\end{array}$ & 76,78 & aktif \\
\hline 8 & Interaksi siswa dalam diskusi kelompok & 74,11 & aktif \\
\hline & Rerata & 75,87 & aktif \\
\hline
\end{tabular}

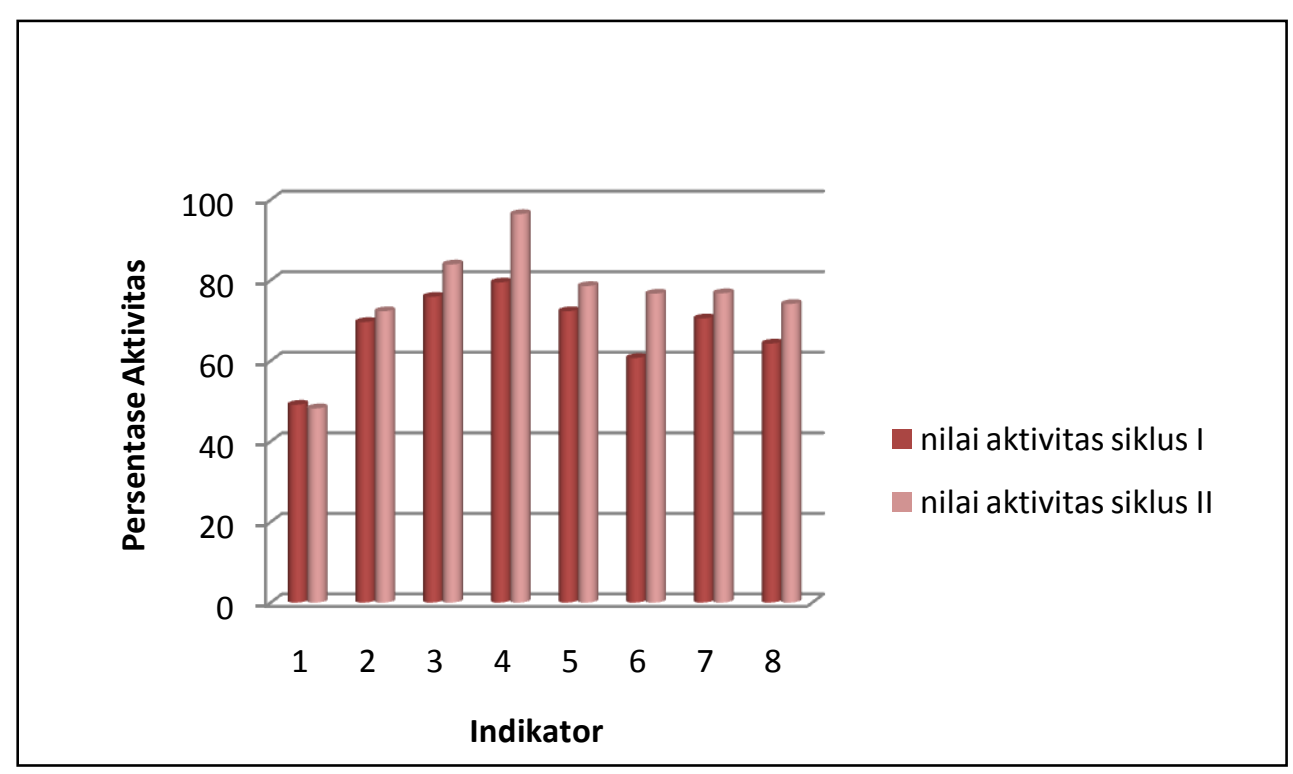

Gambar 2. Grafik Rerata Aktivitas Siswa 
Wari Prastiti - Penerapan Pembelajaran Kooperatif ...

Oleh sebab itu guru bersama tim lesson study sangatlah perlu untuk merancang kegiatan kelompok dengan benar untuk mencapai pembelajaran yang bermakna dan efektif .

Pada indikator kemampuan siswa dalam bertanya baik pada siklus I dan siklus II masih menunjukkan hasil aktivitas belajar kurang aktif. Hal ini dimungkinkan karena keterampilan yang dimiliki guru ketika memberikan pertanyaan kepada siswa masih kurang.

Berdasarkan catatan temuan dari guru observer didapat bahwa pertanyaan yang dilontarkan kepada siswa mendadak dan kalimatnya kurang dimengerti. Selain itu budaya siswa yang masih kurang baik, apabila ada kawan yang bertanya atau menjawab terkadang masih dicemooh oleh siswa yang lainnya.

\section{PENUTUP}

\section{Kesimpulan}

1. Penerapan pembelajaraan kooperatif tipe Numbered Head Together dapat digunakan sebagai alternatif pembelajaran dalam rangka meningkatkan partisipasi belajar siswa dalam proses pembelajaran fisika di kelas XI
$\mathrm{IPA}_{1}$ SMA Negeri 5 Metro tahun pelajaran 2014/2015.

2. Peningkatan partisipasi siswa dalam pembelajaran fisika ini mengindikasikan bahwa perangkat pembelajaran yang direncanakan secara bersama antara guru model dan tim melalui lesson study efektif digunakan. Hal ini terlihat dari keterlibatan siswa dalam pembelajaran mengalami peningkatan dari siklus I sebesar $67,74 \%$ menjadi $78,87 \%$ pada siklus II.

\section{Saran}

1. Pembelajaran fisika hendaknya bervariasi dan tidak monoton sehingga diperoleh kualitas pembelajaran yang maksimal.

2. Perencanaan pembelajaran secara kolaborasi antara guru model dan tim lesson study hendaknya dilaksanakan secara kontinu agar tercipta pembelajaran yang lebih berkualitas.

3. Mengingat pelaksanaan Penelitian Tindakan Kelas ini hanya dua siklus, maka kepada guru yang akan melaksanakan penelitian yang sejenis diharapkan dapat lebih ditingkatkan kualitasnya misalnya dari segi frekuensinya. 
Wari Prastiti - Penerapan Pembelajaran Kooperatif ...

\section{DAFTAR PUSTAKA}

Arikunto, Suharsimi.1988. Penilaian Program Pendidikan . Jakarta: Bina Aksara.

Chatib, Munif. 2014. Sekolahnya Manusia. Bandung: Kaifa.

Chotimah, Husnul, Yuyun Dwitasari. 2009. Strategi - strategi Pembelajaran untuk Penelitian Tindakan Kelas . Malang: Surya Pena Gemilang.

Daud,Firdaus,Muhammad Mifta Fausan. 2011. Penerapan Model Pembelajaran Kooperatif Tipe Numbered Head Together Untuk Meningkatkan Aktivitas dan Hasil Belajar Pada Konsep Ekosistem Bagi Siswa Kelas VII.A SMPN Takalar. Jurnal Chemica. Vol 12 No I. Hal 40 46. Juni 2011.

DIKTI. 2010. Panduan Pelaksanaan Lesson Study di LPTK. Jakarta Kemendiknas.

Hendayana, Sumar. 2012. Pengembangan Karakter Guru dan Dosen Melalui Lesson Study. Makalah disampaikan dalam Seminar Nasional di Universitas Muhammadiyah Metro.

IDCJ, Tim Pelita (Program Peningkatan Kualitas SMP/MTs) .2012. Buku Petunjuk Guru untuk pembelajaran yang lebih baik. IDCJ (International Development Center of Japan). Jakarta.

Novelensia. 2014. Penerapan Pembelajaran Kooperatif Tipe Numbered Heads Together (NHT) disertai Metode Eksperimen dalam
Pembelajaran Fisika di SMA. Skripsi. Universitas Jember.

Sanjaya, Wina.2011. Perencanaan dan Desain Sistem Pembelajaran. Jakarta: Kencana Prenada Media Group.

Syamsuri, Istamar, Ibrohim.2007.

Lesson Study (Studi

Pembelajaran) Model

Pembinaan Pendidik secara

Kolaboratif dan Berkelanjutan. Malang: FMIPA UM.

Trianto. 2010. Mendesain Model Pembelajaran Inovatif Progresif. Jakarta: Kencana Prenada Media Group.

Undang - Undang Republik Indonesia Nomor 20 Tahun 2003 tentang Sistem Pendidikan Nasional. 